\title{
A Study to Assess the Nursing Students Experience Regarding Online Classes During Covid-19 Lock Down Periods in SRM College of Nursing, Kattankulathur, Kancheepuram District-603203, Tamil Nadu, India
}

\author{
C. Kanniammal ${ }^{1}$, T. Suseelal ${ }^{1}$, P. Malarvizhi ${ }^{2}$, P. Vijay Daniel Raj ${ }^{2}$ \\ ${ }^{1}$ Dean, ${ }^{1}$ Associate Professor, ${ }^{2}$ Assistant Professor, ${ }^{2}$ Tutor, SRM College of Nursing, SRM Institute of Science \& \\ Technology, Kattankulathur, Kancheepuram-603 203, Tamil Nadu, India
}

\begin{abstract}
Covid-19 is a dreadful communicable disease which brought dramatic changes in the Education system globally. Online zoom classes are conducted all over the world to teach and guide the students, so that the academic year will not be wasted. The present study aims to explore the learning experience of nursing students regarding online classes during Covid-19 lockdown periods and to associate the learning experience of nursing students with the demographic variables. A single blinded quantitative study with purposive sampling technique, 250 B.Sc. Nursing students were enrolled in this study. Demographic variables and 23 questions on teaching, learning and difficulties of online classes were used in a 5 point likert scale. Data was collected by sharing the questions in Google dox format to the students. The result of the study revealed high level of satisfaction with maximum score of 63.0 and minimum score of 26.0. This result was significant with the mean value of 46.21 and the standard deviation of 7.32. The association of the learning experience of nursing students with the demographic variables was significant with the year of study of the participants. Hence the research hypothesis formulated in this study was proved.
\end{abstract}

Keywords: Covid-19, Online classes, Lock down period, Teaching, Learning, Difficulties, Nursing students experience.

\section{Introduction}

Now a days Covid-19 virus is predominant globally. It is a dreadful communicable disease causing severe morbidity and mortality. Educational system is facing multiple challenges to complete the academic curriculum of 2020. Meticulous planning and guidance from the academician, professor's and teacher's is essential to shift the classroom teaching to online Education. The online

\section{Corresponding Author:}

\section{Dr. T. Suseelal}

College of Nursing, SRM Institute of Science and Technology, Kattankulathur, Kancheepuram, District-603203, Tamil Nadu, India

Phone No.: 9952943319

e-mail: suseelal.john@gmail.com
Education has several technological advancement which has to be adapted by the teachers and students. India is a developing country giving the best education for all age groups. Online classes through media is valuable. Students are able to communicate with video and audio and clear all doubts with teachers. Home environment will be good to concentrate without emotional and physical strain ${ }^{1}$

In our daily work technology is used in maximum areas and it is the part and parcel of our life. Since the schools and colleges are closed due to lockdown digital and Microsoft zoom classes can be promoted by the universities. It will be flexible and economical ${ }^{2}$. Virtual education is emerging all over the world. Faculties and students has to develop skills to online teaching mode. The parents has to understand and cooperate. So that the academic curriculum can be completed without any loss for the students. ${ }^{3}$ 
Worldwide around 1.5 billion students are learning in on line mode. Many students do not have wifi connection and high-fi cell phone. The parents must buy the necessary gadgets and they should supervise their children to gain maximum benefit from on line classes. Most of the students are interested in virtual education. The teachers has to provide adequate content in advance. So that the students will be aware of their lessons. Many new advancement are available which can be used by the teachers. ${ }^{4,5}$

Previous studies revealed the control method of influenza. That time school education were modified. ${ }^{6}$ Since this online education is new to the students few students reported eye strain and head ache. It can be solved by adjusting the class time. ${ }^{7}$

One of the study done on the impact of Covid-19 and higher education revealed that students were unaware of the classes and there was lack of personal touch and interaction. It can be tackled by the teachers by enquiring the students individually. The parents has to give their full support and motivate their students to cooperate with the current scenario. ${ }^{8}$

Another study done in Maharashtra, India stated that some of the students reported positive impact on online classes and few students reported about lack of concentration. However online classes are very useful except network issues which can be rectified. It is the responsibility of the Universities to support their professor's and teacher's in completion of the curriculum and conduction of on line examination to promote the students. ${ }^{9}$ with this great vision the faculty of SRM College of Nursing intended to assess the Nursing students experience regarding online classes during Covid- 19 lockdown period. This study was done after 4 months of online education.

\section{Material and Method}

The study was conducted through online among B.Sc. Nursing students of SRM College of Nursing in the month of August 2020. B.Sc. Nursing students 250 were enrolled by purposive sampling technique. Demographic variables include were age, gender, course of study, device used by students to attend online classes, online media used by teachers.
Arround 23 self-structured questions were developed in Google dox form on 3 domains such as teaching, learning and difficulties of online classes in a likert scale with 5 points. In teaching dimension effectiveness of teaching method used by the faculty, response to online classes and the students satisfaction on the online teaching were included. In learning dimension effectiveness of understanding learning process, positive effect regarding university exam, ideas on future online classes and their interest to traditional learning were included. Regarding online difficulties the students over all stress level in online classes, stress due to Covid -19 disease condition, students feelings on online versus traditional lectures, problem on internet issues, time to read and physical problems experienced were included. One open ended question on their suggestions regarding teaching, learning and difficulties faced in virtual classes was included.

After the correction of the tool by the experts in Medical Surgical Nursing, pilot study was done among 10 students in online. The reliability of the tool was tested by test retest method and the $\mathrm{r}$ value 0.8 was found to be reliable. The questionnaire was found feasible to proceed to the main study.

The Google form questionnaire was shared to the students in on line to the participants. The collected raw data was spread in the Excel master coding sheet and it was analysed using statistical package for social sciences (spss- 16). The p value of 0.05 level was used for statistical significance.

\section{Results}

Regarding the frequency and percentage distribution of the demographic variables revealed majority of the participants among 250 B.Sc. Nursing Students 204 $(81.6 \%)$ belongs to $18-20$ years, females were 206 $(82.4 \%)$, majority of them $240(96.0 \%)$ used smart phone for the online classes and around $10(4.0 \%)$ students used laptop. Regarding method of teaching majority of the teachers 241 (96.4\%) used the zoom app and the Google class room on line was used by 7 teachers $(2.8 \%)$. 

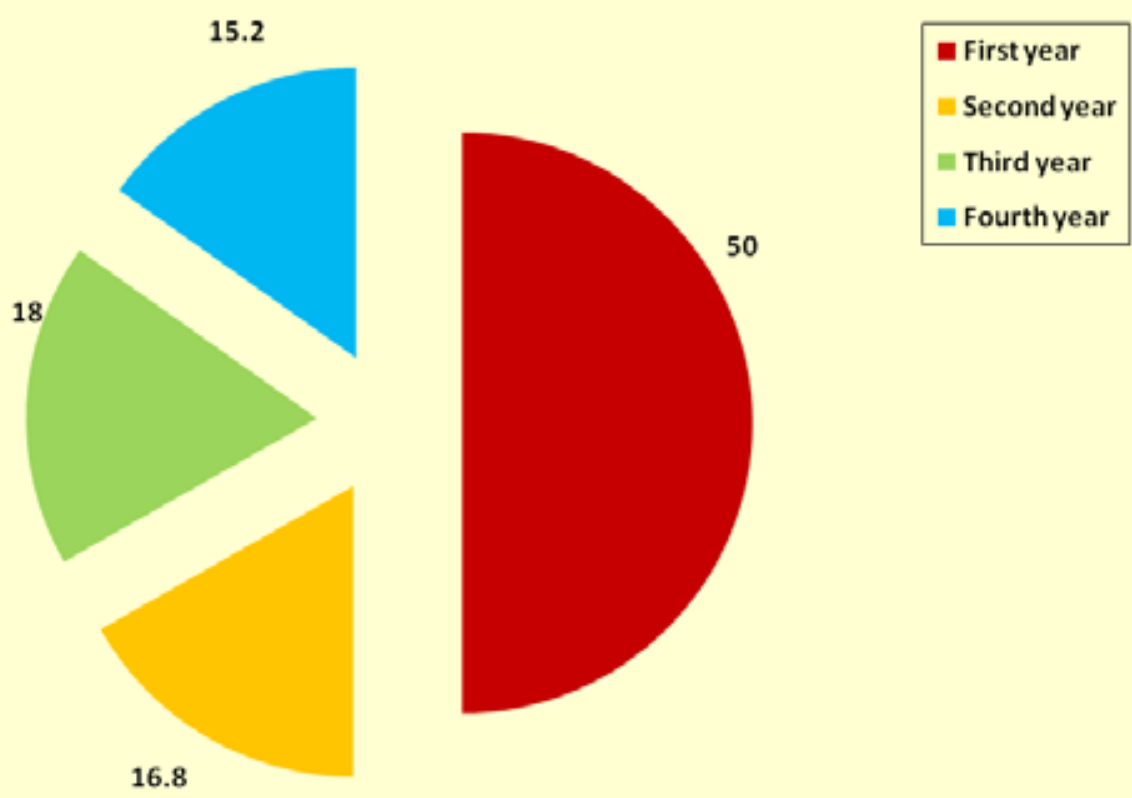

Fig. I. Percentage distribution of year of study of nursing students

Table 1: Frequency and percentage distribution of level of learning experience among nursing students. $\mathbf{N}=\mathbf{2 5 0}$

\begin{tabular}{|l|c|c|}
\hline Learning Experience & No. & \% \\
\hline Unsatisfied (1-21) & 0 & 0 \\
\hline Satisfied (22-42) & 71 & 28.4 \\
\hline Highly satisfied (43-63) & 179 & 71.6 \\
\hline
\end{tabular}

The above table reveals majority of the students $179(71.6 \%)$ were highly satisfied and $71(28.4 \%)$ of the students were satisfied with the on line classes done by the teachers.

Table 2: Assessment of mean and standard deviation of learning experience score among nursing students. $\mathbf{N}=\mathbf{2 5 0}$

\begin{tabular}{|l|c|}
\hline Variables & Score \\
\hline Minimum Score & 26.0 \\
\hline Maximum Score & 63.0 \\
\hline Mean & 46.21 \\
\hline Standard Deviation & 7.32 \\
\hline
\end{tabular}

The above table reveals high level of satisfaction with maximum score of 63.0 and minimum score of 26.0. This result is significant with the mean value of
46.21 and the standard deviation of 7.32. Hence the study is significant.

The association of the learning experience of nursing students with their demographic variables was significant with the year of study of the participants. Other variables like age, gender,course of study, device used by students to attend online classes, online media used by teachers were not associated with the demographic variables.

\section{Discussion}

The present study on assessing the experience of Nursing students about online classes during Covid -19 lock down period is the need of the hour. This is the first time the Nursing faculty and students of SRM College of Nursing were exposed to online classes. It is believed that during this lock down period students are having many difficulties to understand the classes. There is no motivation, no social interaction and the students are psychologically upset due to the distraction and lack of support at home. Some of the students have very poor net work coverage and the students had head ache due to continuous online education mode. The students were convinced by the teachers and by weekly 3 classes and individual phone calls and watsup messages students were happy to cooperate with the classes. 
In this study 250 B.Sc. Nursing students participated. The findings of the present study revealed that majority of the students 179 (71.6\%) were highly satisfied and $71(28.4 \%)$ of the students were satisfied with the on line classes done by the teachers. The result of the study revealed high level of satisfaction with maximum score of 63.0 and minimum score of 26.0. This result was significant with the mean value of 46.21 and the standard deviation of 7.32. The association of the learning experience of nursing students with the demographic variables was significant with the age group of the participants. Hence the research hypothesis formulated in this study was proved.

This result is supported by the study ofDr. Anjana kannankara (2020) on E-learning the Best Bet during lockdown. The study states that online learning will facilitate to face the challenge of working in this new environment as well as embrace the new opportunities to everyone. Hence, this study can be done in other areas of education to facilitate the online education. ${ }^{10}$

\section{Conclusion}

The present study high light the success of the online teaching and learning programme of B.Sc. Nursing students during this Covid-19 pandemic period. The teaching faculty and the students has to adapt new learning method for the completion of the curriculum. The parents has to help and motivate the students in continuous learning process during this critical situation. This study can be done in other areas of education to develop knowledge and confidence among the students.

Acknowledgement: The Dean and team of Medical Surgical faculty conceived and designed the study and collected the data. Analysis was done by Mr. Arvind statistitian. Interpretation and drafting of the article was done by Dr. T. Suseelal, P. Malarvizhi and Mr. P. Vijai Daniel Raj. Dean, college of Nursing has done the final revision and approval of version to be published.

Conflict of Interest: The authors declared no competing interest.

Ethical Clearance: Ethical approval was obtained from the SRM University research committee who follows WHO standards and the 1964 Helsinki declaration and its later amendments.

\section{Source of Funding: Self}

\section{References}

1. Shatakshi L, Nardav S. CoVid-19 Unmasking the new face of Education among the students' studying at Graphic Era Hill University, Dehradun, Uttarakhand, India. IJ Research Pharm Sci. 2020; 11(1):48-53

2. VeenaS, Sheetal M, Navita V.COVID 19 Lockdown Technology Adaption, Teaching, Learning, Students Engagement and Faculty Experience in Banglore. Muktshabd. 2020; 10(4),698-702

3. Giorgi B, David K. Transition to Online Education in Schools during aSARS-CoV-2 Coronavirus (COVID-19) Pandemic in Georgia. Pedagogical Research. 2020; 5(4) : 2-9

4. Daniel J. Education and the COVID-19 pandemic. 2020.

5. Vikram R. J, Bagul TD, Sagar R A. COVID-19 era: students' role to look at problemsin Education system during lockdown issues in Maharashtra. I J Research and Review. 2020; 7(5): 328-33

6. Russell M. V, Simon J R, Helen C, Joseph W, Claire S, et al ., School closure and management practices during coronavirus outbreaks including COVID 19: a rapid systematic review. 2020; 4 (5) : 397-404

7. Wei B. COVID-19 and online teaching in higher education: Human behavior and emerging technologies. A case study of Peking University. 2020; 2 (2):

8. Amit K. A, Srinivasan R. Impact of Pandemic COVID-19 on the Teaching - Learning Process : A Study of Higher Education Teacher Manages. Indian journal of management. 2020; 13 (4) :43-56

9. Vikram R. J, Tushar D, Bagul, Sagar R.A. COVID-19 Era: Students' Role to Look at Problems in Education System during Lockdown Issues in Maharashtra. India IJ Research and Review. 2020; 7 (5): 328- 33

10. Anjana K.E.-Learning: The Best Bet during lock down. 2020. 